\title{
E-Voting and Village Head Election (Case Study on the Election of the Village Head of Pamutih, Pemalang Regency)
}

\author{
Dian Iskandar \\ \{dianiskandar@live.undip.ac.id\} \\ Universita Diponegoro, Indonesia
}

\begin{abstract}
Pemalang Regency in 2018 held a simultaneous village head election with the e-voting system. The transition from traditional elections to e-voting has become an issue in the community. but there is a trust issue in the e-voting system. Pamutih village is one of 172 villages that held elections using a voting approach with an e-voting system. Pamutih is categorized in the red zone because it is considered prone to conflict. Therefore, this article aims to examine how the implementation of the e-voting system in the election of village heads in Pamutih. To answer these questions, then I use a qualitative method with data collection techniques is an interview and study documentation. The results showed that the implementation of E-voting in Pamutih village head election was a success. All stages proceeded smoothly, due to the massive socialization and ability of the committee to create a public trust to the e-voting system, which had implications for the high participation at the time of the vote, and also support from local government. The use of e-voting can guarantee the principles of direct democracy, honest and fair, confidential, accurate and fast. The problems that have appeared during the traditional village head elections can be overcome, such as no more embezzlement and double voters, as well as no errors and fraud in vote counting. Thus, the less human control and technology used in elections will create a better quality of elections, and also the conflict of election results will be decreased.
\end{abstract}

Keywords: Village Head Election, E-voting, Pamutih.

\section{Introduction}

Democracy requires substantive consolidation, both on a local and national scale. Mochtar Mas'oed in the book of political sociology by Zainuddin Maliki mentioned that there are 5 conditions for the consolidation of democracy, one of which is a democratic system that has legitimacy, geography, constitution and politics which is carried out through the election process [1]. An election is used as the main instrument for political education so that public political awareness is higher. Voting in the election is one of the many forms of political participation, especially in a democratic country like Indonesia. Voting is the minimum size for participation. Voting directly affects certain power formations, and voting also has a high intensity of conflict if it is not managed properly and optimally.

The election in Indonesia still uses conventional ways, especially the president, legislative and local head election, except village head election. In recent years an e-voting application (offline not using the internet) has been developed which assists organizers in the 
speed and accuracy of voting and vote counting. Agency for Assessment and Application of Technology of Republic Indonesia and PT Inti develop applications and technology for the implementation of clean, intrigue, honest, fair and accurate elections. Therefore, the use of evoting as an innovation that creates general elections "with additions" is fast and accurate. It's just that the implementation is done in the village head election.

In 2016 the first Village Head Election with E-voting System was held in Pemalang Regency, but due to e-voting as an innovation, the Village Head Election with E-voting System was optional [2]. In 2018 the Pemalang district held a simultaneous village head election with the e-voting system in 172 villages [3] "Forcing" to change the way people vote has implications for social and political conditions [4], and the role of election organizers will be more complex and different when they enter the election process. The use of technology in the election even small elections like village head elections will be a challenging job and requires careful planning. Therefore, the Pemalang Regency government consulted with Agency for Assessment and Application of Technology of Republic Indonesia, the Republic of Indonesia Ministry of Home Affairs, central java government on the idea of the everification, e-voting, and e-recapitulation village head election. Socialization and gathering of community aspirations in 14 sub-districts in Pemalang Regency by involving the village head, village consultative body, village social institutions, community leaders and religious leaders of academic studies together with academics and harmonization by the village government. ${ }^{1}$ The use of technology in the election of village heads is adoption and is seen as a sign of improvement in the democratic process at the village level, and has a significant impact. Evoting as innovation must be introduced to citizens as voters, but this is a challenge because evoting is related to substantive matters, namely, verification of voters, voting and counting process. E-voting lessens human "control" directly in these 3 things [5]. In the implementation, e-voting can fix many issues in the conventional village election, but also in innovation there are several problems, especially in the socio-political situation of the society. Consequently, e-voting can be a trigger and get criticized so the emphasis is on the trust of citizens in using this technology. The use of e-voting in the village head election is considered to make the election process more efficient. E-voting provides solutions to improve sound security, speed, and ease in calculating results. Even so, many challenges must be considered, if not e-voting can damage trust in the process of village head election. This paper forms on the assumption that changes in voting methods in the village head election with e-Voting system will affect instability in community politics, therefore, this article focuses on examining the Pamutih village as a case study to see how the implementation of the e-voting system in the election of village heads in Pamutih.

\section{Research Method}

This article aims to examine how the implementation of village head elections in Pamutih village in the Pemalang Regency use the e-voting system. The use of case studies is due to several things; seen from the specificity, this article takes a different path from mainstream research on village head election, this article aims to elaborate on the usage of technology in the implementation of village head election. Second, considering that this study highlights the implementation of the village head election with the e-voting system, then from

${ }^{1}$ B. Sutopo, Interviewee, Legalitas Evoting di Kabupaten Pemalang 2018. [Interview]. 2 May 2019. 
the dimensions of the region and period in 2018 the Pamutih village is one of 172 organizing village head elections with the e-voting system in Pemalang Regency.

The locus of this study, viz Pamutih Village, Pemalang Regency, Central Java Province, was chosen based on three reasons. First, Pemutih Village is the village with the most final voter list in the simultaneous implementation of the village head election stage VIII compared to 13 other villages. Second, competing contestants are the same incumbent and challenger in the previous village. Third, the election of the village head of Pamutih is considered as a conflict-prone. The focus of this study is on the implementation of the village head election with the e-voting system

This research uses a qualitative approach, the method used is a qualitative analysis obtained from a literature study and in-depth interviews about the implementation of village head elections with an e-voting system. After that, the data is reduced by checking by selecting, focusing and simplifying and abstracting the rough data that you have. Furthermore, the data has been reduced, analyzed the theoretical flow, then classified or categorized according to the order of discussion and adjusted to the purpose of the study. The final step is to conclude. From the data that has been analyzed, the researcher draws conclusions related to the findings of the research that has been done.

\section{Result and Discussion}

In the election of village heads with an e-voting system in Pamutih Village, Pemalang Regency there are four stages of the election [6]:

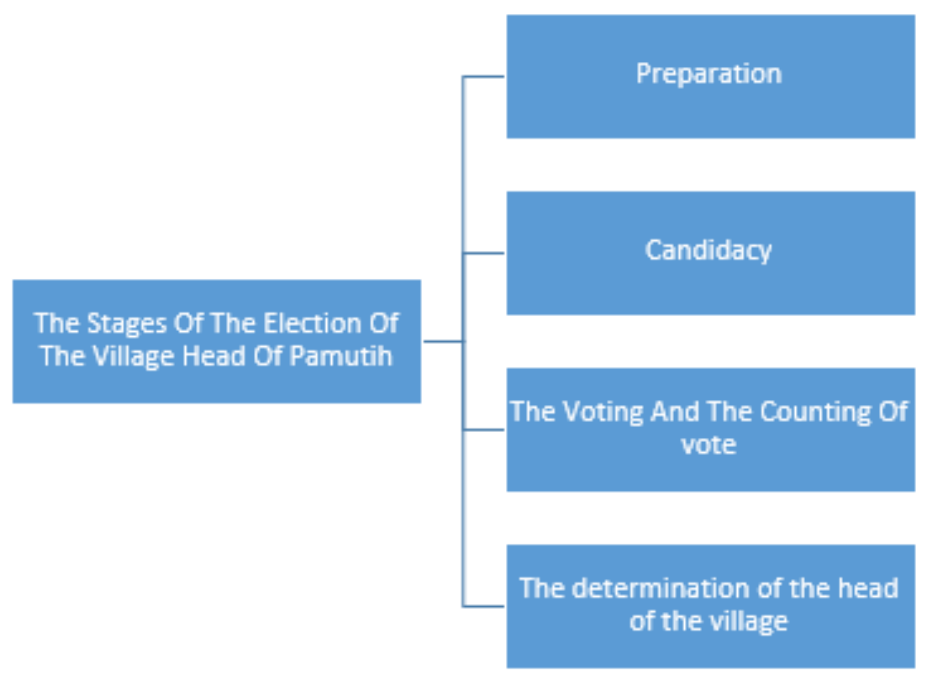

Fig. 1. The stages of organizing the village head election of Pamutih.

Before preparing, the Pemalang government conducted an evaluation with all the Village Consultative Body that would hold village head elections, to provide knowledge and briefing on how to connect and simultaneously elect the village head election system using e-voting. The debriefing was given by the Pemalang Regency village head election organizing a team to 
make regulations on the election of village heads that apply to regional regulations and regent regulations.

In the preliminary stage, several activities were carried out 1) preparation stage was done by forming the committee of Pamutih village head election, consisting of elements of village administrators and village societies as well as forming of a supervisory team. 2) Briefing with the election committee and supervisory team facilitated by the Pemalang Regency government. The debriefing was carried out together with election council from other villages who also held village head elections. 3) Arranging activity schedules, arrange village head election committees and temporary voter list. 4) E-voting socialization. Concerning the village head election system, with the e-voting, the committee considered that democracy requires a substantial basis. Hence, the socialization of the community is carried out to the public so that the construction of the village head election takes place smoothly, and can create justice based on the use of tools that have been tested for eligibility. The socialization was carried out seven times by using the face-to-face method with the society and using digital media to provide an overview of the use of e-voting in the elections, ${ }^{2}$ the massive socialization so that voters easily adopt these innovations. Socialization was carried out by the Pamutih village head election committee.

At the candidacy stage, the committee carries out several activities including 1) Announcement of registration of prospective candidates, 2) Determination of final voter list, 3) registration of prospective candidates, research of administrative requirements file of prospective candidates, announcements of passing nominations for administration of candidates, announcement of names of prospective candidates, tests health, the written examination of candidates for village heads, the announcement of candidates who are entitled to be elected, the delivery of vision and mission, and the implementation of the campaign. At this stage, it is identified that there was a 6,103 final voter list. Meanwhile, three village head candidates consisted of incumbents, challengers from the previous period, and new challengers [3].

The voting and the counting vote stage. the voting in Pamutih village is stage VIII in the election of village heads simultaneously in Pemalang Regency which is held on October 21, 2018. The voting is conducted from 07.00 to 13.00 WIB at the Pamutih village hall. The day before the vote was held; all tools were examined and tried by the election committee, the main technical team and the field technical team, observers from each candidate for the village head and the society. Before votes, the voter must verify by attaching an ID card (KTP) to the electronic KTP reader, then using fingerprint identification to determine that the voter is listed in the final voter list, so there are no more double voters and "smuggling voters "Which usually happens in conventional elections. Furthermore, a voting ballot booth that is equipped with e-voting tools, voters choose candidates and then confirmed through the printed receipt. ${ }^{3}$ Moreover voting on a ballot booth is equipped with e-voting tools. Voters choose candidates and then confirmed through the printed receipt. The use of e-voting in the village head election is easy even old people can use that. The next step is a recapitulation of results with erecapitulation system.

\footnotetext{
${ }^{2}$ Khosirin, Interviewee, Pelaksanaan Evoting di Desa Pamutih 2018. [Interview]. 31 July 2019.

${ }^{3}$ K. Giovani, Interviewee, Tata Cara Pemungutan Suara electronik di Kabupaten Pemalang 2018. [Interview]. 3 May 2019
} 
The recapitulation results are sent directly to the data center and automatically recapitulated, and distributed through the website https://pemalangkab.go.id/evoting/ ${ }^{4}$ Through the site, the public can find out who will lead in the Pamutih village for the next 6 years because of the results real count. The vote count result of the total votes entered in Pamutih village was 4,629 votes won by Candidate number 2 with 2,655 votes. The following are the details of vote acquisition in table 1.

Table 1. The Results of the Vote Count for the Village Head of Pamutih

\begin{tabular}{clccc}
\hline No & \multicolumn{2}{c}{ Candidate } & Total vote & Presentase $(\%)$ \\
\hline 1 & 1 (new challenger) \\
2 & $\begin{array}{l}\text { (challengers } \\
\text { previous period) }\end{array}$ from & 601 & 12,98 \\
3 & 3 (incumbent) & 2.655 & 57,36 \\
& Total & 1.360 & 29,38 \\
\hline
\end{tabular}

Source: https://www.pemalangkab.go.id/evoting.

\subsection{Massive Socialization and Local Government Support as Determinant Factor}

The implementation of the village head election with the e-voting system in Pamutih was included in the success category. In terms of implementation, there were no problems, all stages proceeded well from the preparation stage to the determination of results election. From the side of voter participation, it is known that $75.85 \%$ of the people participated in the 2018 village head election. Therefore, two factors influence the success of voting in the village head election in Pamutih. First, the massive socialization. As an innovation Introducing e-voting becomes a challenge because this technology touches the core of the voting and counting process. In its implementation, e-voting reduces direct human control. This condition provides an opportunity to fix some of the problems with traditional village head elections. E-voting systems are fundamentally different, e-voting is seen as a tool that makes democratic superior, strengthen trust in management and the credibility of the election results and gives efficiency in electoral processes.

Therefore, the committee did various ways to increase the interest and trust of the people to vote. The ability of the committee to convince the public is very good by saying that evoting provides a solution in increasing ballot security, quickness, and efficiency and transparency in calculating results and e-voting is built on a solid technical basis. In the context of socio-political support that can help significantly in the introduction of e-voting, the massive socialization by building trust has an impact on voter participation to come to polling stations to vote, because they are enthusiastic about trying a new system in the Pamutih village head election and supported by socio-political conditions in the Pamutih village community.

The second factor is support from the local government. Pemalang district government in the context of organizing village head elections simultaneously does several things such as creating a legal framework in the form of local regulations governing the simultaneous village head elections procedure with the e-voting system, forming village head elections organizing teams, technical teams, and supervisors, and providing guidance and training as well as supporting some e-voting financing.

${ }^{4}$ K. Giovani, Interviewee, Tata Cara Pemungutan Suara electronik di Kabupaten Pemalang 2018. [Interview]. 3 May 2019. 


\section{Conclusion}

The E-voting in Pamutih village head election was a success. All stages proceeded smoothly, due to the massive socialization and ability of the committee to create a public trust to the e-voting system, which had implications for the high participation at the time of the vote. The more massive the socialization of an innovation (e-voting) and visible differences before and after used e-voting, it will increase political participation in voting. Also, the support of the local government in giving a positive vibe to the Pamutih village head election.

The experience of e-voting in Pamutih provides a clear reflection. The use of e-voting can guarantee the principles of direct democracy, honest and fair, confidential, accurate and fast. The problems that have appeared during the traditional village head elections can be overcome, such as no more embezzlement and double voters, as well as no errors and fraud in vote counting. Thus, the less human control and technology used in elections will create a better quality of elections, and also the conflict of election results will be decreased.

\section{References}

[1] Z. Maliki, Sosiologi politik: makna kekuasaan dan transformasi politik. UGM PRESS, 2018

[2] F. E. Nugroho, "Pertama di Indonesia, Pilkades di Pemalang Pakai Sistem e-Voting," Liputan 6, 2016. [Online]. Available: https://www.liputan6.com/regional/read/2611228/pertama-diindonesia-pilkades-di-pemalang-pakai-sistem-e-voting. [Accessed: 01-Jul-2019].

[3] Kabupaten Pemalang, "E Voting," pemalangkab.go.id, 2018. [Online]. Available: https://www.pemalangkab.go.id/evoting/. [Accessed: 01-Jul-2019].

[4] J. P. Gibson, R. Krimmer, V. Teague, and J. Pomares, "A review of e-voting: the past, present and future," Ann. Telecommun., vol. 71, no. 7-8, pp. 279-286, 2016.

[5] I. IDEA, "Introducing Electronic Evoting: Essential Considerations," 2011.

[6] Kabupaten Pemalang, Keputusan Bupati Kabupaten Pemalang Nomor 141.1/386/2018 Tentang Pelaksanaan Pemungutan Suara Pemilihan Kepala Desa Serentak Di kabupaten Pemalang Tahun 2018. 2018. 